\title{
MORFOLOGI PEMBUNGAAN DAN SISTEM REPRODUKSI MERBAU (Intsia bijuga) PADA PLOT POPULASI PERBANYAKAN DI PALIYAN, GUNUNGKIDUL
}

Flowering morphology and reproductive system of Merbau (Intsia bijuga) at macro propagation plot in Paliyan, Gunungkidul

\author{
Liliana Baskorowati dan Sugeng Pudjiono \\ Balai Besar Penelitian Bioteknologi dan Pemuliaan Tanaman Hutan \\ Jl. Palagan Tentara Pelajar Km. 15, Purwobinangun, Pakem, Sleman, Yogyakarta, Indonesia \\ e-mail: lbaskorowati@yahoo.com
}

Tanggal diterima : 9 Juli 2015, Tanggal direvisi : 31 Juli 2015, Disetujui terbit : 2 November 2015

\begin{abstract}
Information regarding the flowering morphology, as a first step to understand the reproductive system, is essential. The purpose of this study is to determine the flowering morphology and the reproductive systems of merbau. Observation of flowering and fruiting intensity was undertaken every week for 6 consecutive months, from May to November 2013. Observations of the development of generative organs were carried out on daily basis to determine the duration and the length of each development stage of flowers and fruits. Results showed that flowering of merbau is arranged in spikes, hermaprodite with un-synchronous flowering between and within spikes. Reproductive organs are protandry and apparently heterostyly type, indicating that self-incompatibility may occur in this species. None fruit was formed from self-pollination experiment; supporting the allegation of crosspollination systems (xenogamy). Flowering occurs twice a year with peak flowering in June and November, followed by fruit maturation in the next 3 months. Various types of insect visitors found during this study, however very few insect can be determined as pollinators. Flowers and pollinator limitation lead to the mechanism of self-incompatibility causing low reproductive success on this species. Therefore, an artificial cross-pollination or an introduction of pollinators needs to be done in order to enhance the reproductive success of this species.
\end{abstract}

Keywords: $\quad$ Merbau, Intsia bijuga, flowering morphology, reproductive system, heterostyly, protandry

\begin{abstract}
ABSTRAK
Informasi tentang morfologi pembungaan sebagai langkah awal mengetahui sistem reproduksi untuk menentukan langkah konservasi sangat diperlukan. Tujuan penelitian ini adalah untuk mengetahui morfologi pembungaan dan sistem reproduksi merbau. Pengamatan intensitas pembungaan dan pembuahan dilakukan setiap 1 minggu sekali selama 6 bulan mulai bulan Mei hingga November 2013. Pengamatan perkembangan organ generatif dilakukan setiap hari untuk mengetahui tahapan perkembangan bunga dan buah.Hasil penelitian menunjukkan bahwa pembungaan tersusun dalam malai, hermaprodit dengan kemasakan bunga yang tidak serempak. Organ reproduksi bertipe heterostyly dan bersifat protandry. Tidak terdapat buah yang terbentuk dari hasil percobaan dengan penyebukan sendiri (self-pollination). Hal ini memperkuat dugaan tentang sistem polinasi silang (xenogamy). Pembungaan terjadi dua kali setahun dengan puncak pembungaan Juni dan November, diikuti dengan kemasakan buah pada 3 bulan berikutnya. Terdapat berbagai macam serangga yang mengunjungi bunga merbau, namun sangat sedikit serangga penyerbuk yang ditemukan pada populasi uji. Rendahnya keberhasilan reproduksi selain dikarenakan sedikitnya jumlah bunga dan serangga pengunjung, juga karena adanya ketidakcocokan berkawin sendiri, sehingga upaya melakukan perkawinan silang atau memperbanyak serangga penyerbuk perlu dilakukan.
\end{abstract}

Kata kunci: Merbau, Intsia bijuga, morfologi pembungaan, sistem reproduksi, heterostyly, protandry 


\section{PENDAHULUAN}

Intsia bijuga (Colebr.) Kuntze yang umumnya disebut dengan merbau merupakan tanaman hutan yang habitat alamnya tersebar di daerah Australia, kepulauan Pasific, Papua New Guinea,Indonesia, Malaysia, Thailand dan Vietnam sedangkan di Indonesia merbau banyak di temukan di daerah Papua. Merbau merupakan jenis yang potensial untuk dikembangkan karena kekuatan dan keawetan kayunya yang sangat bagus dengan berat jenis 0,63-1,04 dan merupakan kayu dengan kelas kuat I-II serta memiliki penyusutan kayu yang sangat rendah sehingga tidak mudah cacat apabila dikeringkan (Tharman et. al., 2006). Oleh karena itu kayu merbau banyak digunakan sebagai bahan konstruksi berat, balok, bantalan dan tiang. Pemenuhan kebutuhan kayu jenis tersebut masih dilakukan dari penebangan hutan alam, sehingga potensinya semakin menurun. Berdasarkan kategori IUCN Red List (1994) status konservasi Intsia bijuga sudah termasuk kategori rawan (VU A1cd).Upaya mempertahankan jenis ini sudah dilakukan oleh B2PBPTH Yogyakarta, antara lain dengan pembangunan beberapa plot konservasi exsitu, pembangunan plot hasil populasi perbanyakan vegetatif serta pembangunan plot uji keturunan (B2PBPTH, 2007).
Upaya-upaya konservasi yang sudah dilakukan diatas perlu didukung dengan informasi mengenai sistem reproduksi, termasuk didalamnya informasi mengenai morfologi pembungaan, struktur pembungaan dan sistem perkawinan yang terjadi.

Pengetahuan yang rinci mengenai waktu pembungaan dan fenologi pembungaan sangat penting untuk mengetahui keberhasilan reproduksi. Menurut House (1997) keberhasilan reproduksi dapat diketahui secara jelas ketika tersedia informasi seperti musim, waktu, lama dan intensitas pembungaan maupun pembuahan. Penelitian tentang pembungaan berperan sangat penting dalam dinamika populasi sebuah jenis, karena keberhasilan perkawinan dapat dilakukan dengan cara meningkatkan atau menunda pembungaan (Griffin, 1980; Sedgley \& Griffin, 1989). Lebih lanjut dikatakan oleh Sedgley and Griffin (1989) bahwa pengetahuan tentang morfologi pembungaan akan menentukan pola perkawinan sebuah jenis, dan hal tersebut sangat penting dalam menentukan strategi mengelola suatu populasi untuk dapat menghasilkan benih yang baik. Selain itu, pengetahuan tentang serangga penyerbuk atau pengunjung sebuah jenis sangat penting dipahami untuk dapat menentukan keberhasilan reproduksinya (Frankie \& Haber, 1983). 
Sejauh ini penelitian tentang morfologi pembungaan jenis merbau belum banyak dilakukan. Informasi tentang pembungaan dan cara permudaan sejauh ini masih bersifat umum (Yudohartono \& Ismail, 2013; Tharman et. al., 2006). Oleh karena itu, penelitian ini dilakukan dengan tujuan (1) Mengetahui morfologi pembungaan merbau; (2). Mengetahui tahapan dan intensitas pembungaan dan pembuahan merbau; dan (3). Mengetahui sistem reproduksi dengan menghitung keberhasilan reproduksi merbau.

\section{BAHAN DAN METODE}

\section{A. Lokasi Penelitian}

Penelitian dilakukan pada plot populasi perbanyakan merbau yang terletak di Petak 93, Paliyan Gunungkidul,Yogyakarta $\left(8^{\circ} \mathrm{LS}\right.$ dan $110^{\circ}$ 29' 59” BT). Rancangan awal plot ini menggunakan Rancangan Acak Lengkap Berblok dengan 120 pohon induk dan 3 pohon per plot, jumlah ulangan 5 blok dan ditanam dengan jarak tanam $6 \times 2 \mathrm{~m}$. Namun demikian, pada waktu penelitian dilakukan sudah banyak pohon yang mati, sehingga pengamatan pembungaan dan pembuahan dilakukan pada 35 pohon yang masih tersisa di blok 1 .

\section{B. Metode Penelitian}

Pengamatan waktu berbunga dan berbuah serta intensitas perbungaan merbau dilakukan dengan menghitung jumlah malai bunga/inflorescences (bukan individu bunga) dan buah muda pada semua pohon yang terdapat pada blok 1 . Jumlah malai bunga dan buah pada tiaptiap pohon dicatat pada setiap pengamatan. Pengamatan intensitas pembungaan dan pembuahan tersebut dilakukan setiap minggu selama 6 bulan berturut-turut dari bulan Mei hingga November. Pengamatan pembungaan dilakukan dengan menghitung jumlah malai pada masingmasing individu. Pengamatan perkembangan organ generatif terutama terhadap munculnya tanda-tanda perbungaan, terbentuknya bunga dan perkembangan menjadi buah; dilakukan setiap hari. Pengamatan panjang waktu berlangsungnya tahap perkembangan organ generatif dimulai sejak tahap inisiasi bunga, yaitu saat tunas reproduktif tampak secara makroskopis sampai buah dan biji masak. Pengamatan organ generatif dilakukan pada 3 pohon dengan bunga yang melimpah.

Pengamatan terhadap sistem perkawinan pada jenis ini dilakukan dengan mengadakan percobaan menghitung keberhasilan reproduksi (jumlah buah vs jumlah bunga yang berhasil didapatkan) dengan 
membandingkan penyerbukan alam dan penyerbukan sendiri. Pengamatan dilakukan terhadap 3 pohon dengan bunga melimpah. Pada masing-masing pohon contoh, ranting pohon dengan malai diberi label tanggal dimulainya pengamatan kemudian dilakukan perhitungan jumlah kuncup bunga. Untuk percobaan penyerbukan alam, maka malai dibiarkan terbuka, sedangkan untuk percobaan penyerbukan sendiri dilakukan dengan cara menutup malai yang mengandung bunga-bunga yang siap mekar dengan pollination bag (Baskorowati, 2006). Dua minggu setelah perlakuan, kantong penyerbukan dibuka, dan dihitung jumlah bunga yang sudah terbuahi. Perhitungan keberhasilan reproduksi dilakukan dengan cara membandingkan jumlah bunga sebelum mekar dengan jumlah buah yang terbentuk.

\section{Pengamatan agen penyerbuk} dilakukan pada puncak pembungaan pada beberapa pohon yang mempunyai bunga yang melimpah. Pengamatan dilakukan pada pagi, siang dan sore hari, masingmasing selama 5 menit selama tiga hari berturut-turut. Jumlah serangga yang mendatangi dan melakukan kontak dengan bunga dicatat dan dihitung, sedangkan contoh serangga dikoleksi dengan cara menangkap menggunakan jaring untuk proses identifikasi lebih lanjut. Data serangga dan hewan yang menggunjungi bunga selama lima menit pengamatan dikonversi kedalam logaritma, yang kemudian dianalisis menggunakan REML analisis (GenStat 8), dengan jenis serangga sebagai efek tetap dan sampel pohon sebagai efek random. Model analisis varian yang digunakan adalah sebagai berikut:

$$
\begin{aligned}
& \mathbf{Y i j}=\boldsymbol{\mu}+\rho \mathbf{i}+\boldsymbol{\varepsilon} \mathbf{i} \\
& \text { Yij = Rata-rata jumlah serangga pada } \\
& \mu \quad=\text { Rerata umum } \\
& \text { oi } \quad=\text { Pengaruh dari ulangan ke } \mathrm{i} \\
& \text { cij } \quad=\text { Pengaruh sisa (residual) }
\end{aligned}
$$

\section{HASIL DAN PEMBAHASAN}

\section{A. Morfologi bunga}

Bunga merbau tumbuh terminal atau tumbuh pada ujung ranting (Gambar 1). Merbau mempunyai bunga majemuk tidak terbatas (indeterminate), dengan pertumbuhan bunga yang monopodial, karena pucuk ibu tangkai bunga tumbuh terus, dan bunga-bunga mekar bertipe acropletal (dari bawah ke atas). Bunga majemuk bersifat tak terbatas karena tidak memiliki bunga terminal yang sejati. Ujung ibu tangkai bunga biasanya berupa pucuk yang mengerdil (rudimenter). Kedudukan bunga terminal, dengan demikian, diisi oleh bunga subterminal (bunga di bawah pucuk). 


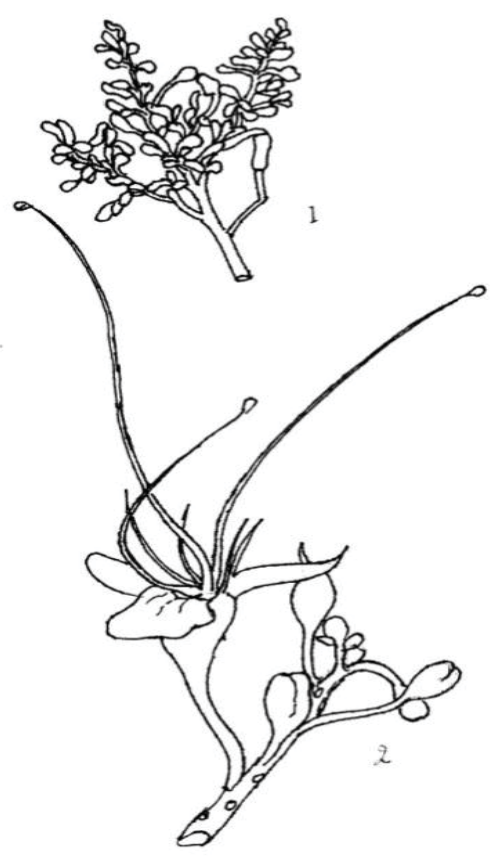

Gambar 1. Morfologi perbungaan merbau (1: skala 1: 1, 2: Skala 1:5 oleh Inorontoko, 2015)

Tabel 1. Ukuran dari struktur bunga merbau (Intsia bijuga)

\begin{tabular}{lcrr}
\hline \multicolumn{1}{c}{ Pengukuran } & Satuan & Rerata & Standar error \\
\hline Jumlah bunga per inflorescences & buah & 20,60 & 1,91 \\
Diameter kuncup bunga (1 minggu setelah terbentuk) & $\mathrm{mm}$ & 3,30 & 0,45 \\
Panjang kuncup bunga (1 minggu setelah terbentuk) & $\mathrm{mm}$ & 1,80 & 0,25 \\
Lebar kuncup bunga (1 minggu setelah terbentuk) & $\mathrm{mm}$ & 2,02 & 0,09 \\
Diameter kuncup bunga (ketika anthesis) & $\mathrm{mm}$ & 5,04 & 0,26 \\
Panjang kuncup bunga (ketika anthesis) & $\mathrm{mm}$ & 25,50 & 1,13 \\
Lebar kuncup bunga (1 minggu setelah terbentuk) & $\mathrm{mm}$ & 5,55 & 0,30 \\
Panjang putik (1 hari setelah anthesis) & $\mathrm{mm}$ & 47,50 & 1,59 \\
Panjang benang sari (1 hari setelah anthesis) & $\mathrm{mm}$ & 34,40 & 1,16 \\
\hline
\end{tabular}

Bunga merbau mempunyai organ betina dan pejantan dalam satu bunga (hermaprodit), yaitu mempunyai putik (terdiri dari kepala putik dan tangkai putik) sebagai organ betina dan benang sari (terdiri dari kepala sari dan tangkai sari) sebagai organ jantan dalam satu bunga. Bunga-bunga tersusun dalam satu malai/inflorescences, dengan jumlah bunga yang beragam dalam satu malai (rerata kuncup bunga 20,60 $\pm 1,19$ ). Perkembangan bunga dari kuncup sampai ke bunga masak tidak serempak dalam satu malai, dengan kecenderungan mengikuti perkembangan bunga yang acropetal yaitu bunga mengalami kemasakan dari bawah menuju ke atas. Morfologi bunga yang semacam ini memungkinkan peluang yang besar terjadinya kawin sendiri (autogamy) yang 
akan menurunkan viabilitas biji karena adanya penurunan sifat baik suatu populasi. Kuncup bunga akan mengalami perkembangan ukuran dari ketika mulai terlihat secara makroskopis sampai mencapai ukuran maksimal ketika akan anthesis (Tabel 1). Masing-masing individu bunga merbau memiliki 3 benang sari yang merupakan tempat kepala sari serta memiliki 1 buah putik, dengan 1 mahkota bunga yang berwarna pink atau putih serta 4 kelopak bunga. Ukuran dari struktur bunga merbau ditampilkan pada Tabel 1.

Bunga merbau juga bertipe heterostyly (Gambar 2) yakni ukuran putik lebih panjang daripada benang sari (pin), atau sebaliknya (thrump). Seperti disajikan dalam Tabel 1, terlihat bahwa rerata panjang putik adalah 47,50 $\pm 1,59 \mathrm{~mm}$; sedangkan rerata panjang benang sari 34,40 $\pm 1,16$ mm. Menurut Barret (1992), heterostyly merupakan suatu bentuk polimorfisme pada tumbuhan, khususnya pada bunga. Pada spesies tumbuhan yang heterostyly, terdapat dua atau tiga tipe morfologi bunga yang berbeda pada suatu populasi tumbuhan tersebut. Perbedaan morfologi bunga tersebut antara lain terletak pada perbedaan panjang benang sari dan putik. Ciri fenotipe yang tampak ini berhubungan secara genetik dengan gen yang bertanggung jawab pada sistem ketidakcocokan berkawin sendiri (self- incompatibility). Pada sistem selfincompatibility tersebut, tepung sari dari satu bunga tidak dapat menyerbuki bunga lain dengan morfologi yang sama. Perbedaan panjang benang sari dan putik pada bunga yang heterostyly teradaptasi untuk terjadinya penyerbukan oleh agen penyerbuk yang berbeda. Tepung sari yang berasal dari stamen yang panjang (tipe thrump) akan menyerbuki kepala putik yang panjang (tipe pin). Apabila perpindahan benang sari antara dua bunga terjadi pada tipe morfologi yang sama, maka tidak akan terjadi pembuahan karena mekanisme self-incompatiibility. Dari hasil pengamatan, sebagian besar merbau mempunyai type heterostyly-pin, sehingga kemungkinan terjadinya perkawinan sendiri dalam satu pohon sangat kecil. Dengan demikian perpindahan serbuk sari sangat membutuhkan pollinator untuk mendapatkan bunga dengan type heterostyly-thrump agar dapat terjadi kecocokan perkawinan.

Lebih lanjut, bunga merbau hanya mempunyai 3 kepala sari sebagai sumber tepung sari. Jumlah ini sangat sedikit mengingat kebutuhan tepung sari untuk penyerbukan sangat besar. Kepala putik pada umumnya masak setelah tepung sari pecah, sehingga bunga merbau termasuk dalam kategori protandry. Tipe kemasakan bunga yang protandry juga merupakan salah satu mekanisme bunga untuk 
mencegah terjadinya kawin sendiri, karena pada umumnya terjadi ketidaksamaan waktu kemasakan kepala putik dan membukanya tepung sari dalam satu malai sehingga menghambat terjadinya kawin sendiri/autogamy (Richards, 1997).

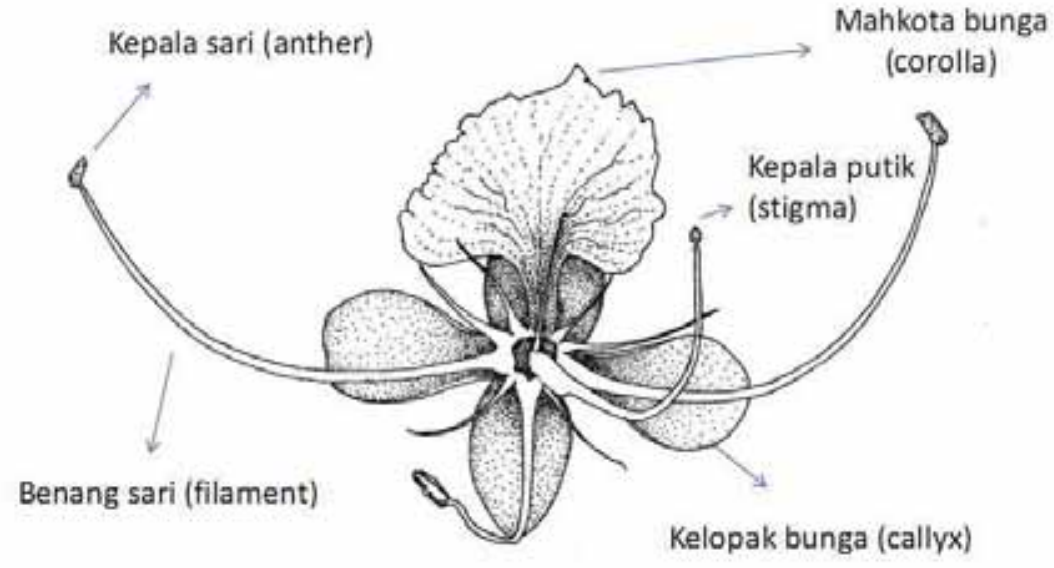

Gambar 2. Organ reproduksi merbau dengan 1 putik, 3 benang sari dan bertipe heterostyly-pin (Skala 1:5 oleh Inorontoko, 2015)

\section{B. Tahapan perkembangan organ generatif, intensitas pembungaan dan pembuahan}

Secara umum perkembangan organ generatif merupakan serangkaian tahapan yang dimulai dari (1) tahap induksi bunga;(2) tahap inisiasi bunga atau preanthesis; (3) tahap pembungaan atau anthesis; (4) tahap penyerbukan dan pembuahan; (5) tahap perkembangan buah menuju kemasakan (Hartmann \& Kester, 1961). Hasil pengamatan perkembangan organ generatif jenis merbau adalah sebagai berikut:

(1). Tahap induksi bunga. Induksi bunga merupakan tahap pertama dari proses pembungaan dimana meristem vegetatif secara seluler berubah menjadi meristem generatif, atau perubahan transisi dari juvenile menuju dewasa (Griffin \& Sedgley, 1989; Hartman \& Kester, 1961). Terjadi di dalam sel, umumnya terjadi peningkatan sintesis asam nukleat dan protein, yang dibutuhkan dalam pembelahan dan diferensiasi sel. Secara makroskopis, perubahan ini umumnya ditandai dengan berbagai ciri seperti: berubahnya bentuk daun, bertambah tebalnya pucuk daun, peningkatan produksi cabang dan ranting, terbentuknya cabang-cabang plagiotropik, ataupun memendeknya internodia (Longman, 1985; Griffin \& Sedgley, 1989). Pada jenis merbau, induksi bunga yang dapat terlihat jelas adalah adanya perubahan ukuran daun yang lebih mengecil serta memendeknya internodia (Gambar 3). Induksi bunga tersebut dapat dijumpai 
dari bulan Desember sampai Januari dan berlangsung selama 25 sampai 30 hari.

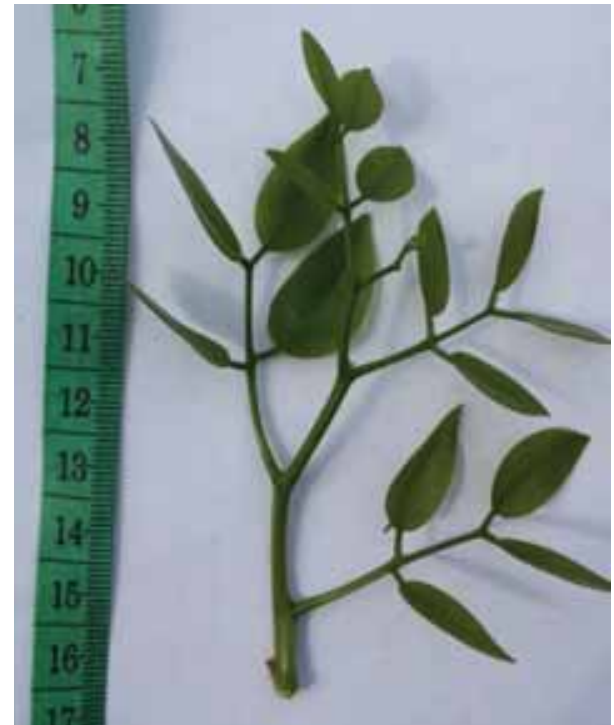

Gambar 3. Induksi bunga merbau dengan ukuran daun yang mengecil (Baskorowati, 2013)

(2). Tahap inisiasi bunga (pre-anthesis). Inisiasi bunga merupakan kenampakan morfologis pertama tunas reproduktif yang dapat terlihat secara makroskopis, yang dapat dideteksi dari perubahan bentuk maupun ukuran kuncup, serta prosesproses selanjutnya yang mulai membentuk organ-organ reproduktif (Griffin \& Sedgley, 1989). Pada merbau inisiasi bunga ditandai dengan munculnya kuncup pembungaan dalam setiap ujung tangkai daun. Terjadinya pembengkakan ujungujung tunas (diferensiasi) yang dimulai dari pangkal tunas dan akhirnya membentuk kuncup bunga majemuk dengan tangkai-tangkai kuncup bunga (Gambar 4a). Secara umum diferensiasi kuncup bunga untuk membentuk bagian-bagian bunga selalu dimulai dari pembentukan tangkai, karena tangkai mengandung meristem sekunder yang berfungsi untuk membentuk bungabunga tunggal (Griffin \& Sedgley, 1989; Eldridge et al., 1993). Selama kurang lebih 30 hari akan terjadi pembengkakan ukuran kuncup bunga sehingga mencapai ukuran maksimal pada hari ke 30-32. Kuncup dengan pembengkakan optimal ditandai dengan membukanya kelopak bunga dan munculnya mahkota bunga. Pada merbau, proses ini akan diikuti dengan munculnya benang sari seperti disajikan pada Gambar 4b.

(3) Tahap pembungaan (anthesis), yaitu tahapan ketika bunga - mahkota bunga beserta organ reproduksinya membuka seutuhnya. Umumnya merupakan tanda bahwa organ reproduksi sudah mencapai kemasakan, meskipun dalam beberapa jenis kemasakan organ reproduksi terjadi sebelum bunga mekar atau sesudah bunga mekar. Pada merbau saat anthesis ditandai dengan membukanya kelopak dan mahkota bunga secara maksimal; diikuti 
tegaknya putik dan benang sari (Gambar 5). Namun demikian pada merbau kemasakan organ reproduktif terjadi selang beberapa saat setelah anthesis, karena tidak ditemukan cairan bening (excudate) pada kepala putik; sedangkan kantong serbuk sari juga masih menutup. Hal ini menandakan belum terjadi kemasakan organ betina maupun pejantan sesaat setelah bunga anthesis.

Gambar 4a

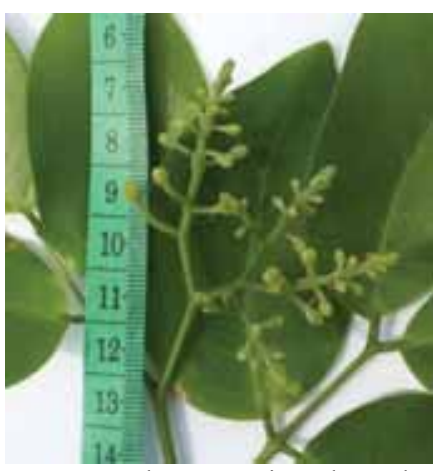
(Baskorowati, 2013)

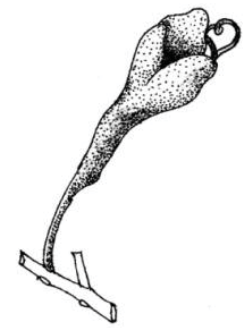

Gambar 4b. Pembengkakan optimal kuncup bunga merbau (Skala 1:5, Inorontoko, 2015)

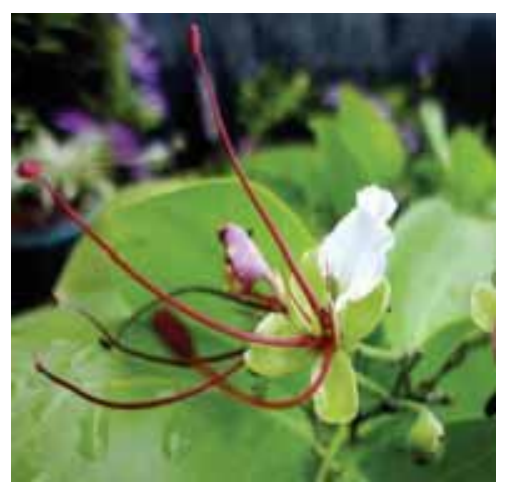

Gambar 5. Bunga merbau tahap anthesis (Creative indeed.net, 2013)
(4) Griffin and Sedgley menyebutkan bahwa penyerbukan merupakan tahap pertama dalam proses reproduksi dan diikuti oleh pembuahan jika penyerbukan berhasil dilakukan. Kemasakan organ jantan (membukanya kantong sari) pada merbau terjadi lebih dahulu daripada kemasakan organ betina (putik). Dengan demikian perkembangan organ reproduksi merbau termasuk bertipe protandry. Bunga mencapai anthesis pada pagi hari diikuti dengan tegaknya benang sari (kantong sari pecah beberapa saat kemudian), diikuti tegaknya putik. Kepala putik mengeluarkan cairan pada tengah hari; tepung sari juga luruh semuanya pada saat itu. Sore hari, kepala putik masih berdiri tegak tetapi cairan sudah mengering, dan benang sari sudah layu (Gambar 6a). Perkembangan selanjutnya mahkota bunga, benang sari dan tangkai putik mengering dan luruh. Ketika sudah terjadi pembuahan maka bakal buah berkembang menjadi buah (Gambar 6b). Perkembangan organ reproduksi merbau dengan tipe protandry seperti tersebut diatas mengindikasikan perkawinan silang (outcrossing) merupakan syarat terjadinya pembuahan (Richard, 1997). Lebih lanjut tipe bunga protandry sangat 
umum dijumpai pada tanaman yang diserbuki oleh serangga dibandingkan dengan tipe bunga protogyny yang

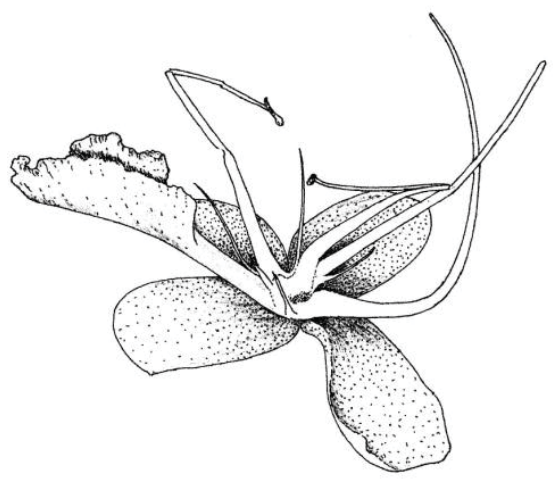

Gambar 6a. Putik dan benang sari mulai layu setelah pembuahan (Skala 1:5, Inorontoko, 2015)

\section{(5) Tahap perkembangan buah menuju}

\section{kemasakan.}

Tahap ini diawali dengan pembesaran bakal buah (ovarium), yang diikuti oleh perkembangan cadangan makanan (endosperm), dan selanjutnya terjadi perkembangan embryo. Pada merbau, perkembangan kuncup bunga, bunga dan buah sampai buah mencapai kemasakan membutuhkan waktu 6-7 bulan. Buah merbau berwarna hijau waktu muda yang akan berubah warna menjadi coklat sejalan dengan kemasakan bijinya. Buah merbau berbentuk polong, pipih, dengan jumlah biji di dalamnya yang bervariasi antara $2-8$ biji (Gambar 7). Bunga yang muncul mendukung terjadinya perkawinan silang (Richard, 1997; Wasser \& Ollerton, 2006).

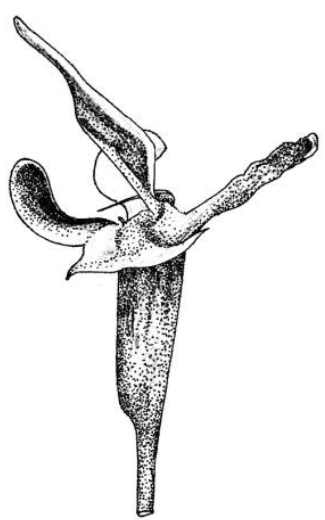

Gambar 6b. Perkembangan bakal buah merbau (Skala 1:5, Inorontoko, 2015)

pada bulan Februari-Maret menjadi biji siap panen pada bulan AgustusSeptember. Terdapat variasi kemasakan buah pada merbau yang berhubungan dengan variasi waktu berbunga. Variasi ini umum terjadi yang umumnya dipengaruhi oleh iklim seperti suhu, cahaya matahari. Merbau di Carita, Jawa Barat, berbunga pada bulan NovemberJanuari, buah akan mencapai kemasakan pada bulan Mei-Agustus; sedangkan Merbau pada plot konservasi ex-situ di Gunungkidul yang mekar pada bulan April-Mei buah akan masak pada bulan AgustusSeptember (Yudoharyono \& Ismail, 2013). 


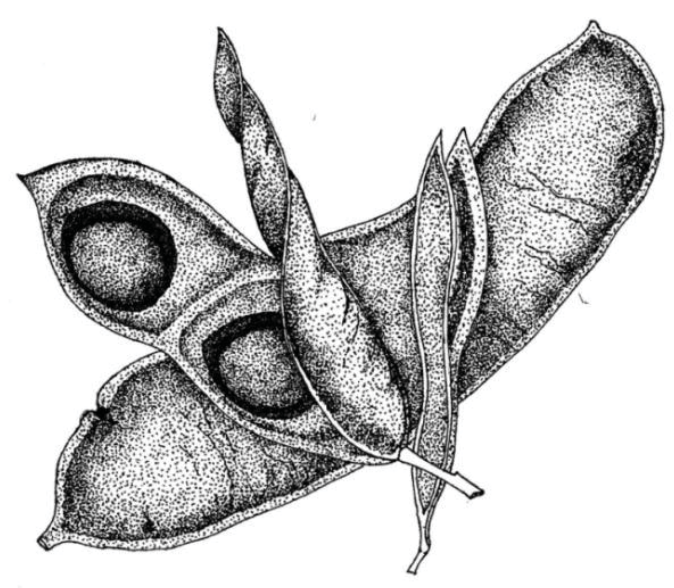

Gambar 7. Buah merbau mencapai kemasakan (Skala 1:5 oleh Inorontoko, 2015)

\section{Panjang waktu berlangsungnya tahap perkembangan organ generatif}

Pengetahuan tentang fenologi digunakan untuk memberikan gambaran mengenai panjang waktu berlangsungnya masing-masing tahap perkembangan organ generative suatu species (Owens et al., 1991). Informasi tersebut sangat berguna terutama untuk kegiatan perkawinan buatan, dimana perlakuan terhadap organ generative seperti pengumpulan pollen, pembastaran maupun perkawinan akan berhasil dengan baik jika dilakukan pada waktu yang tepat. Perhitungan terhadap panjang waktu berlangsungnya masingmasing tahap perkembangan dilakukan sejak tahap inisiasi bunga seperti disajikan pada Tabel 2.

Pengamatan pembungaan dan pembuahan pada plot populasi perbanyakan merbau di Petak 93 KHDTK Paliyan, Gunung Kidul Yogyakarta yang dimulai dari bulan Mei sampai dengan
November 2013 menunjukkan bahwa permulaan kuncup pembungaan sebenarnya sudah terjadi dari bulan Februari, namun bulan Mei merupakan puncak pembungaan dengan intensitas pembungaan tertinggi pada populasi tersebut (Gambar 8).

Hasil pengamatan pembungaan dan pembuahan disini sedikit berbeda dengan penelitian sebelumnya yang melaporkan bahwa pada kebun percobaan konservasi ex-situ di Gunung Kidul maupun di Bondowoso dimulai pada musim penghujan yaitu November sampai pertengahan April (Yudhohartono \& Ismail, 2013), sedangkan Martawijaya (1981) menyebutkan bahwa musim berbunga dan berbuah merbau terjadi pada bulan Juni sampai dengan Oktober. Terdapatnya perbedaan waktu pembungaan dan pembuahan ini umum terjadi pada beberapa spesies, tergantung pada lokasi dan kondisi lingkungan 
setempat. Hal ini umumnya dipengaruhi

oleh faktor genetik maupun faktor biotik

dan abiotik (Smith-Ramirez \& Armesto,

1994; Eldridge et al., 1993; Friedel et al.,

1993; Keatley \& Hudson, 1998). Keatley faktor-faktor yang mempengaruhi pembungaan adalah agroklimat (suhu, curah hujan), kondisi geografi, penyebaran tepung sari dan biji, maupun struktur pembungaan.

and Hudson (1998) mengemukakan bahwa

Tabel 2. Panjang waktu berlangsungnya masing-masing tahap perkembangan pada merbau

\section{Tahap perkembangan}

Satuan pengamatan

Waktu

I. Tahap inisiasi bunga

perkembangan

a. Terbentuk tunas reproduktif hingga terdiferensiasi membentuk

Hari

$25-30$ tangkai dan tunas (Gambar. 4a)

b. Pembengkakan tunas hingga mencapai maksimal, kelopak bunga

Hari

$28-29$ membuka dan mahkota bunga mulaimembuka (Gambar. 4b)

\section{Tahap perkembangan kuncup bunga menuju anthesis}

c. Kelopak bunga membuka maksimal, mahkota bunga jugamengalami perkembangan hingga maksimal (Gambar. 5)

d. Kepala putik mulai tegak dan belum ada cairan; tangkai sari sebagian mulai tegak juga namun kantong tepung sarimasih menutup

e. Semua kantong tepung sari dalam satu kuncup bunga membuka, tepung sari sudah hilang (Gambar. 6a)

III. Tahap penyerbukan dan pembuahan (fertilisation)

f. Bunga mengalami penyerbukan dan pembuahan, ditandai dengan luruhnya mahkota bunga dan benang sari. Tangkai putik yang telah terbuahi masih tertinggal yang akan berkembang menjadi buah (Gambar. 6b)

g. Perubahan morfologisbunga menjadi buah

IV. Tahap perkembangan buah menuju kemasakan

h. Buahmengalami perkembangan ditandai dengan pertambahan diameter dan perubahan warna dari hijau ke coklat gelap

i. Buah masak ditandai dengan pecahnya polong sehingga biji berhamburan (Gambar. 7) Hari 12

Jam

12

Jam

Jam

$1-2$

Hari

4-6

Hari

60

60

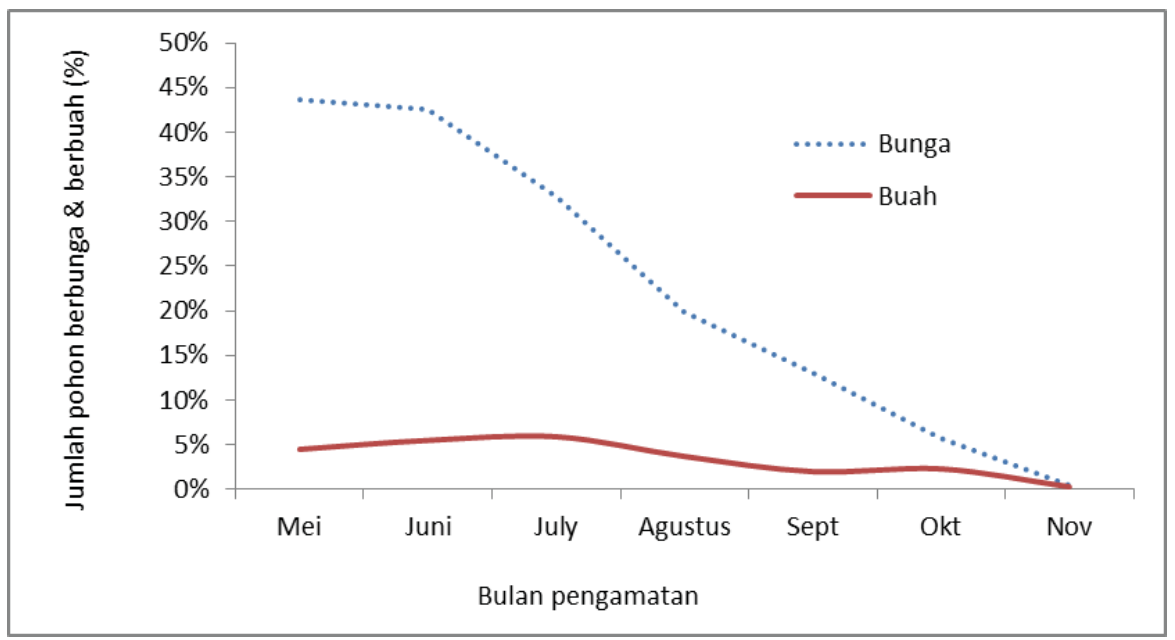

Gambar 8. Rerata pembungaan dan pembuahan mebau pada Plot Populasi Perbanyakan Merbau Petak 93, Paliyan, Gunung Kidul, Yogyakarta 
Hasil penelitian sebelumnya menyatakan bahwa keterbatasan air di Gunung Kidul membuat tanaman sering mengalami cekaman lingkungan berupa kekeringan, yang memacu proses pembentukan bunga (Yudhohartono \& Ismail, 2013). Secara umum, pembungaan merupakan tanggapan terhadap turunnya ketersediaan air dalam tanah, karena cekaman air yang diikuti oleh hujan seringkali merangsang pembungaan tanaman (Pook et al., 1997). Perbedaan dalam pembungaan juga berhubungan dengan kondisi lingkungan (Florence, 1964; Pryor, 1976; Ashton, 1979; Law et al., 2000). Kelembaban tanah dan curah hujan yang tinggi sebelum perkembangan kuncup bunga pada umumnya diindikasikan sebagai faktor penting pembentukan kuncup bunga dan perkembangan bunga (Porter, 1978; Moncur \& Boland, 1989; Law et al., 2000).

\section{Keberhasilan Reproduksi}

Pembuahan merbau terjadi juga pada bulan-bulan pengamatan dengan jumlah yang sangat rendah (kurang dari 6\%). Hal ini juga diperkuat dengan hasil percobaan keberhasilan reproduksi yang memperlihatkan tingkat keberhasilan reproduksi alam yang sangat rendah yaitu hanya $2,7 \%$ (Gambar 9).
Rendahnya hasil biji pada penyerbukan alam dan tidak terbentuknya biji sama sekali pada penyerbukan sendiri pada pohon contoh menunjukkan bahwa sistem perkawinan dalam merbau merupakan perkawinan silang (obligate outcrossing) dan mengindikasikan terdapatnya ketidakcocokan berkawin sendiri (self-incompatibility). Selfincompatibility mungkin dihasilkan dari beberapa mekanisme seperti gagalnya pollen menempel ke kepala putik dari bunga yang sama ataupun gagalnya pollen tubes tumbuh dan berkembang di dalam stylus (de Nettacourt, 1977; Richard, 1997). Tipe bunga yang hererostyly memang menunjukkan bahwa merbau mempunyai kecenderungan besar melakukan penyerbukan terbuka atau berkawin silang. Penelitian sistem perkawinan pada merbau populasi Papua menggunakan penanda isoenzim menunjukkan bahwa rerata perkawinan silang pada multi lokus $\left(\mathrm{t}_{\mathrm{m}}\right)$ untuk populasi Manokwari dan Kerom sama besar yaitu 1,000 (Ningsih, 2008). Lebih lanjut dinyatakan bahwa nilai biparental inbreeding untuk dua populasi tersebut menunjukkan kemungkinan terjadinya kawin kerabat 2,8\% untuk populasi Kerom dan 1,9\% untuk populasi Manokwari. 


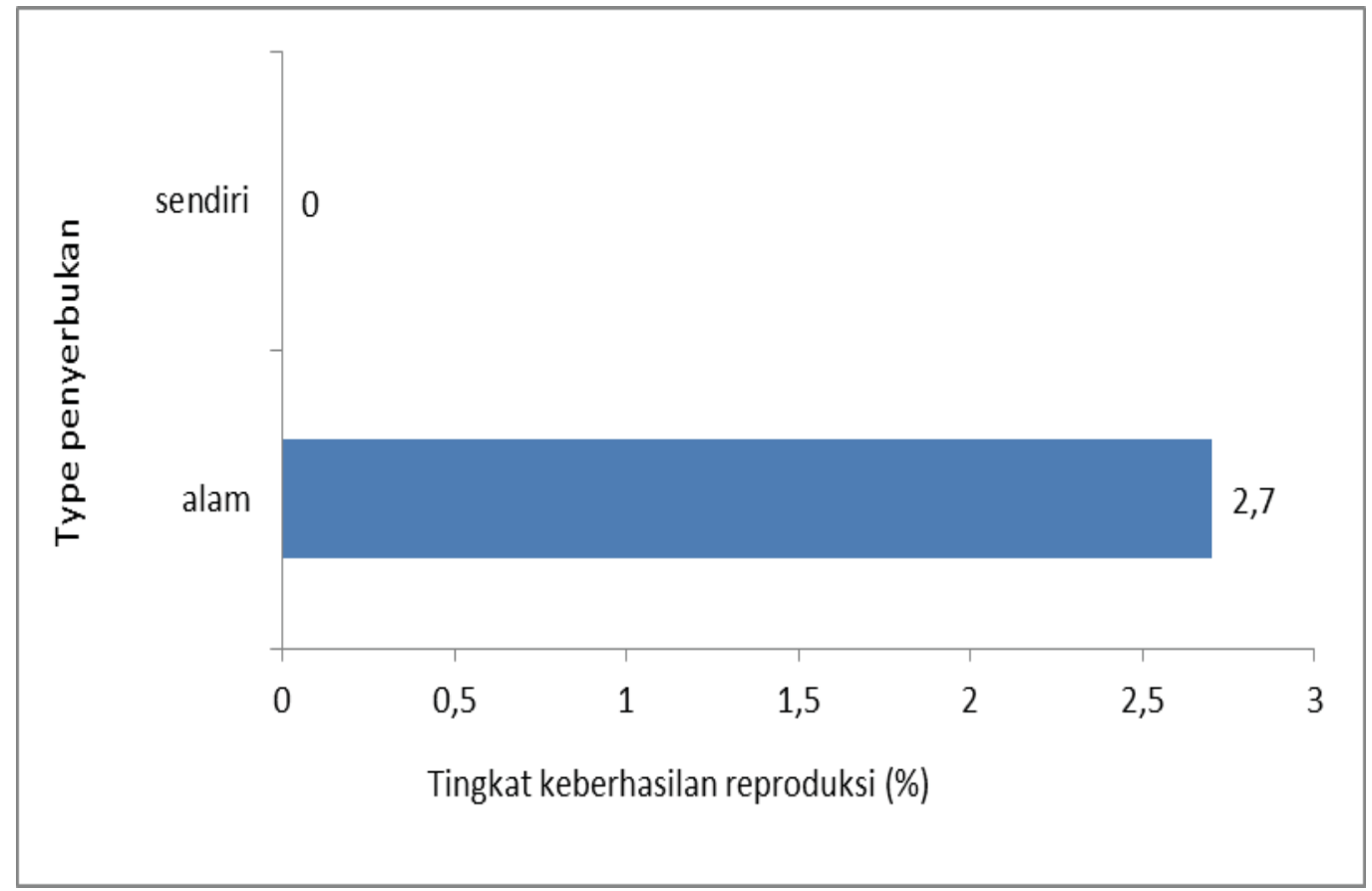

Gambar 9. Keberhasilan reproduksi dilihat dari 2 tipe penyerbukan merbau di Populasi Perbanyakan Merbau Petak 93, Paliyan, Gunung Kidul, Yogyakarta

Rendahnya hasil biji pada plot ini dimungkinkan juga karena pembungaan dalam populasi ini tidak terjadi secara serempak. Pada spesies dengan tipe penyerbukan yang menyilang, ukuran populasi dan kerapatan tegakan umumnya berhubungan dengan kemampuan mengundang penyerbuk dan aktivitas penyerbuk (Moza dan Bhatnagar, 2007). Hal ini dikarenakan populasi yang kecil pada umumnya kurang menarik penyerbuk untuk mendatangi bunga. Hasil penelitian lain menunjukkan bahwa berkurangnya ukuran populasi akan berakibat turunnya hasil benih dikarenakan rendahnya perpindahan tepung sari (Florence, 1964).

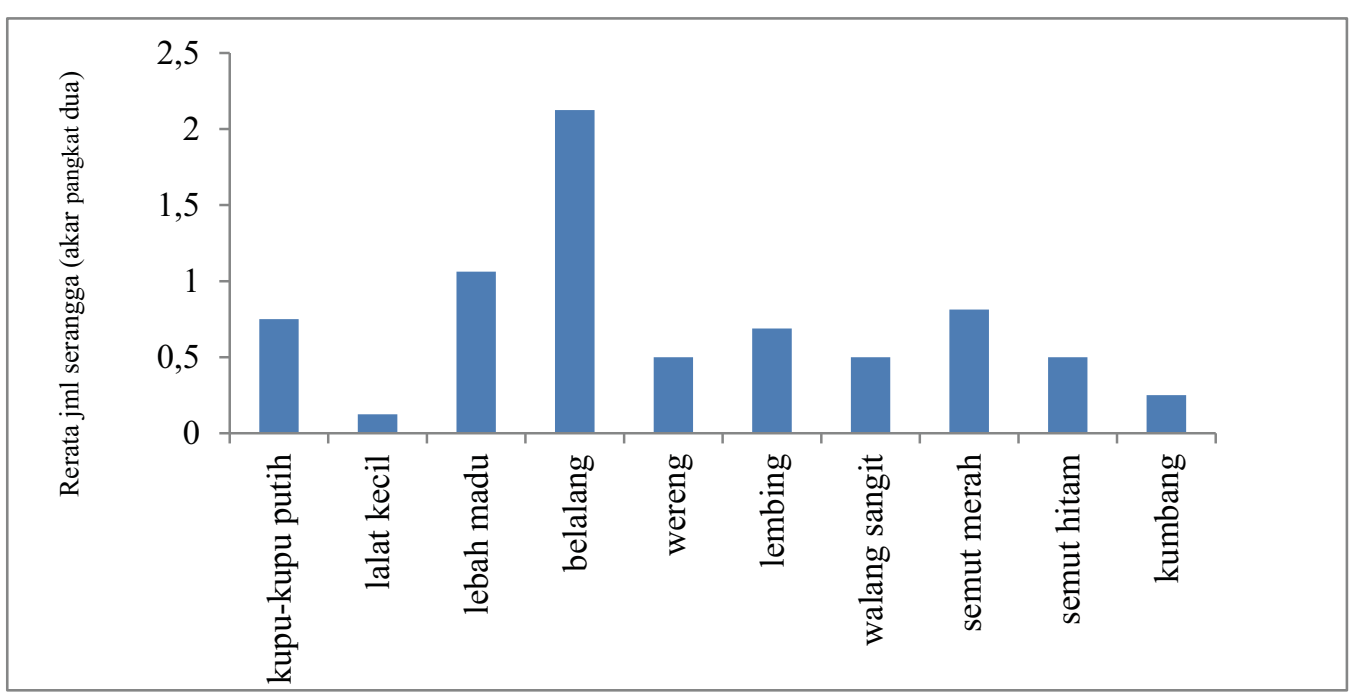

Gambar 10. Jumlah serangga yang mengunjungi bunga merbau diPopulasi Perbanyakan Merbau Petak 93, Paliyan, Gunung Kidul, Yogyakarta 
Ketidakserempakan pembungaan akan mengurangi jumlah serangga yang mendatangi bunga dalam populasi tersebut, yang akhirnya akan berdampak pada berkurangnya perpindahan tepung sari antar pohon. Nektar dan tepung sari adalah unsur bunga yang paling bertanggung jawab untuk menarik serangga mengunjungi bunga, karena nektar menyediakan energi yang dibutuhkan oleh pengunjung bunga (Sedgley \& Griffin, 1989; Kearns \& Inouye, 1993). Bunga merbau hanya mempunyai 1 mahkota bunga yang mengakibatkan jumlah nektar yang dihasilkan akan sangat sedikit, selain itu jumlah tepung sari juga akan sedikit mengingat hanya terdapat 3 anther dalam satu bunga. Hal tersebut kemungkinan juga merupakan penyebab rendahnya jumlah serangga pengunjung pada merbau. Hasil analisis menunjukkan bahwa jenis serangga yang mendatangi bunga merbau berbeda sangat nyata (Chi pr $=<0.001)$, meskipun demikian dari pengamatan serangga pengunjung memperlihatkan bahwa serangga yang banyak mendatangi bunga merbau adalah belalang, diikuti dengan lebah madu dan semut merah (Gambar 10). Thaman et al., (2006) menyatakan bahwa pembantu penyerbukan bunga merbau adalah serangga (lebah), burung dan angin. Kemungkinan yang menjadi serangga penyerbuk merbau di plot penelitian ini juga lebah, meskipun masih diperlukan penelitian yang lebih rinci. Meskipun ditemukan paling banyak jumlahnya, kehadiran belalang kemungkinan tidak berperan sebagai agen penyerbuk yang efektif. Perbedaan jenis serangga yang mendatangi bunga dan sedikitnya jumlah serangga yang mendatangi bunga turut berperan pada rendahnya proses perpindahan tepung sari antar pohon yang akhirnya akan mengakibatkan rendahnya keberhasilan reproduksi (Faegri and van der Pijl, 1979).

\section{KESIMPULAN}

Bunga merbau tersusun dalam malai dengan jumlah $20,60 \pm 1,19$ mempunyai organ betina dan pejantan dalam satu bunga (hermaprodit). Bunga tersusun atas 4 kelopak bunga, 1 mahkota bunga, 1 putik dan 3 benang sari. Kemasakan organ pejantan terjadi lebih dulu diikuti kemasakan organ betina, sehingga termasuk sebagai bunga yang potandry. Bunga mempunyai type yang heterostyly dengan panjang stamen yang lebih panjang dari pada putik (pin) atau stamen lebih pendek dari pada putik (thrump). Perkembangan pembungaan dimulai dengan tahap induksi bunga,yang terjadi 30 hari sebelum kuncup terbentuk, diikuti tahap inisiasi bunga dimana kuncup bunga mengalami perkembangan atau preanthesis yang membutuhkan waktu 28 
hari; selanjutnya tahap anthesis dimana bunga sudah merekah umumnya terjadi 12 jam setelah kuncup bunga berkembang maksimal. Tahapan selanjutnya adalah penyerbukan dan pembuahan yang terjadi beberapa jam setelah anthesis dan diikuti tahap perkembangan buah menuju kemasakan yang memakan waktu 120 hari. Sistem penyerbukan yang terjadi pada merbau diindikasikan sebagai penyerbukan silang (xenogamy). Hal tersebut diindikasikan dari tidak adanya biji yang terbentuk dari hasil penyerbukan sendiri, meskipun tingkat keberhasilan melalui penyerbukan alam juga rendah, yang disebabkan karena rendahnya jumlah serangga penggunjung dalam plot uji. Dalam rangka meningkatkan keberhasilan reproduksi (meningkatkan jumlah biji yang terbentuk), upaya pengelolaan kebun merbau dengan meningkatkan jumlah serangga pengunjung atau dengan melakukan penyerbukan buatan sangat dianjurkan. Pengumpulan tepung sari sebagai tepung sari donor dapat dilakukan pada bulan puncak pembungaan (donor) dengan mengumpulkan bunga-bunga pada tahap anthesis.

\section{UCAPAN TERIMA KASIH}

Penulis mengucapkan terimakasih kepada saudara Heri Effendi, Alin Maryanti, dan Bapak Suroto atas bantuannya dalam pengamatan dan pengambilan contoh di lapangan.

Terimakasih juga penulis sampaikan kepada Burhan Ismail, S.si atas diskusi dan bantuan selama penelitian berlangsung.

\section{DAFTAR PUSTAKA}

Ashton, D. H. (1975). Studies of flowering behaviour in Eucalyptus regnans F. Muell. Australian Journal of Botany, 23, 399411.

Anonim. (2007). Pembangunan populasi perbanyakan vegetative jenis merbau (Intsia bijuga). Laporan Kegiatan 2007, Buku 2. Departemen Kehutanan, Badan Penelitian dan Pengembangan Kehutanan, Balai Besar Bioteknologi dan Pemuliaan Tanaman Hutan.

Barrett, S. C. H. (1992). Heterostylous genetic polymorpisms: model systems for evolutionary analysis on Monographs on: Theoretical and Applied Genetics 15 Evolution and Function of Heterostyly. Heidelberg, Berlin: Springer-Verlag.

Baskorowati, L. (2006). Controlled Pollination Methods for Melaleuca alternifolia (Maiden and Betce) Chell. ACIAR Technical Report 63. Canberra: ACIAR.

Eldridge, K., Davidson, J., Harwood, C., \& van Wyk, G. (1993). Eucalypt Domestication and Breeding, $(322 \mathrm{p})$. Oxford: Oxford University Press.

Faegri, K., \& Van der Pijl, L. (1979). The Principles of Pollination Ecology (3rd ed.). Oxford: Pergamon Press.

Florence, R. G. (1964). A comparative study of flowering and seed production in six blackbutt (Eucalyptus pilularis Sm.) forest stands. Australian Forestry, 28, $28-33$.

Frankie, G. W., \& Haber W. A. (1983). Why bees move among mass-flowering neotropical trees. In C.E. Jones \& R.J. Litte. (Eds.), Handbook of Experimental Pollination Biology (pp 360-372). New York: Scientific and Academic Editions.

Friedel, M. H., Nelson, D. J., Sparrow, A. D., Kinloch, J. E., \& Maconochie, J. R. (1993). What induces central Australian arid zone trees and shrubs to flower and fruit? Australian Journal of Botany, 41, $307-319$. 
Griffin, A. R. (1980). Floral phenology of a stand of mountain ash (Eucalyptus regnans $\mathrm{F}$. Muell) in Gippsland, Victoria. Australian Journal of Botany, 28, $393-404$.

House, S. M. (1997). Reproductive biology of eucalypts. In J. E. Williams \& J. C. Z. Woinarski (Eds.), Eucalypt Ecology (pp. 30-50). Cambridge: Cambridge University Press.

Kearns, C.A., \& Inouye, D. W. (1993). Techniques for Pollination Biologist. Colorado: University Press of Colorado.

Keatley, M. R., \& Hudson, L. (1998). The influence of fruit and bud volumes on eucalypt flowering-an explanatory analysis. Australian Journal of Botany, 46, $281-304$

Law, B., Mackowski, C., Schoer, L., \& Tweedie, T. (2000). Flowering phenology of myrtaceous trees and their relation to climatic, environmental and disturbance variables in northern New South Wales. Austral Ecology, 25, 160 - 178.

Martawijaya, (1981). Atlas Kayu Indonesia 2. Bogor: Balai Penelitian Hasil Hutan, Badan Litbang Pertanian.

Moncur, M. W., \& Boland, D. J. (1989). Floral morphology of Eucalyptus melliodora A. Cunn. ex Schau. and comparisons with other eucalypt species. Australian Journal of Botany, 37, $125-135$.

Moza, M. K., \& Bhatnagar, A. K. (2007). Plant reproductive biology studies crucial for conservation. Current Science, 92, 9.

Ningsih, A. N. (2008). Sistem perkawinan pada sebaran alam merbau (Intsia bijuga (Colebr) O. Kuntze) di Papua berdasarkan analisis isozim (Skripsi). Jurusan Budidaya Hutan, Fakultas Kehutanan, Universitas Gadjah Mada, Yogyakarta.

Pook, E. W., Gill, A. M., \& Moore, P. H. R. (1997). Long-term variation of litter fall, canopy leaf area and flowering in Eucalyptus maculata forest on the South Coast of New South Wales. Australian Journal of Botany, 45, 737 - 755.

Porter, J. W. (1978). Relationships between flowering and honey production of red ironbark, Eucalyptus sideroxylon (A. Cunn.) Benth and climate in the Bendigo district of Victoria. Australian Journal of Agricultural Research, 29, 815 - 829.
Pryor, L. D. (1976). The Biology of Eucalypts. London: Edward Arnold.

Richards, A. J. (1997). Plant Breeding Systems. London: Chapman \& Hall.

Sedgley, M., \& Griffin, A. R. (1989). Sexual Reproduction of Tree Crops. London: Academic Press.

Sedgley, M., Harbard, J., \& Smith, R. M. (1992). Hybridisation Techniques for Acacias. ACIAR Technical Reports No. 20. Canberra: ACIAR.

Smith-Ramirez, C., \& Armesto, J. J. (1994). Flowering and fruiting in the temperate rainforest of Chiloé, Chile-ecologies and climatic constraints. Journal of Ecology, $82,353-365$.

Tharman, R. R., Lex, A, J., Robin, D., Francis, A., \& Craig, R. E. (2006). Intsia bijuga (vesi). Species Profile for Pacific Island Agroforestry. Retrived from http://www.tradionaltree.org

Yudohartono, T. P. \& Ismail, B. (2013). Adaptabilitas, pertumbuhan dan regenerasi pada plot konservasi ex-situ merbau. Jurnal Pemuliaan Tanaman Hutan, 7(3), 179-195. 